\title{
Thomas Merton: The true self and the quest for justice
}

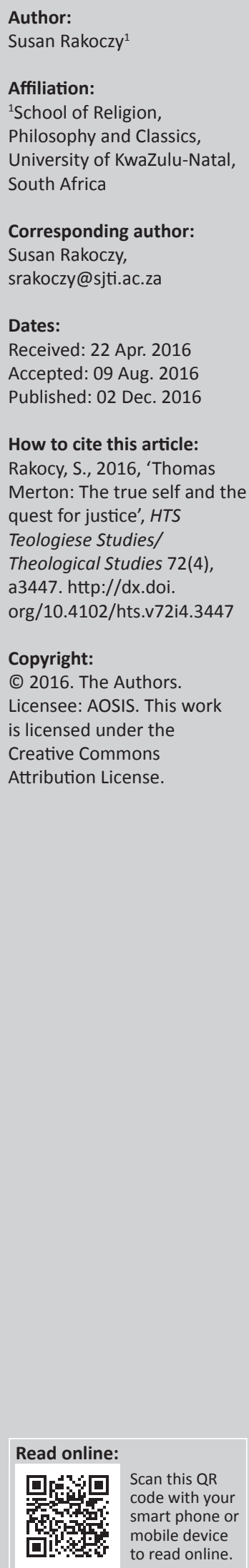

The year 2015 marked the 100th anniversary of the birth of Thomas Merton who was born on 31 January 1915. His writings cover diverse themes, which are of value to a myriad of faith traditions. This article will trace his understanding of holiness and the way in which Merton emphasised participation in the transformation of the world. It commences with a biographical overview of Merton and then Merton's understanding of 'holiness' as growth of the 'true self' in God is discussed. His work as social critic is outlined and the article ends with a reflection of Merton's understanding of 'love' and 'compassion' - a life before God.

\section{Introduction}

The year 2015 marked the 100th anniversary of the birth of Thomas Merton who was born on 31 January 1915. He died aged 53 on 10 December 1968 in Bangkok, Thailand, at an international monastic conference, leaving a huge legacy of writings on diverse themes, which continues to nourish persons of many faiths even today.

This article will trace the development of his understanding of holiness as the growth of the true self in God, an integration of contemplation and the quest for justice. Three years after he died, the Catholic bishops meeting in the synod on social justice stated:

Action on behalf of justice and participation in the transformation of the world fully appear to us as a constitutive dimension of the preaching of the Gospel, or, in other words, of the Church's mission for the redemption of the human race and its liberation from every oppressive situation. (JW 6)

Merton would have said an emphatic 'Amen'.

\section{Biographical background}

Merton was born in France on January 31, 1915; his parents were both artists and they were in France in order to paint. His father Owen was born in New Zealand and his mother Ruth Jenkins was American. He had a younger brother, John Paul, who died during World War II. He was baptised in the Anglican Church in Prades but had an eclectic religious upbringing.

His mother died of stomach cancer when he was six. She wrote him a letter from the hospital saying that:

she was about to die, and would never see me again ... And a tremendous weight of sadness and depression settled on me ... it had 'something of the heavy perplexity and gloom of adult grief. (Merton 1949:24)

From his grandfather ('Pop'), he received 'hatred and suspicion of Catholics' - 'the deep, almost subconscious aversion from the vague and evil thing, which I called Catholicism' (p. 38) and by the time he was nine 'was becoming more and more positively averse to the thought of any religion' (p. 39). His only valuable religious and moral training came from his father - 'not systematically but here and there' - if something spiritual was on his mind, it came out naturally' (p. 70).

His father died of brain cancer when he was 15. About his father's death, he wrote, 'There was nothing I seemed to be able to grasp' (p. 106). During his teens, he travelled in Italy and when he visited Rome, he was attracted by the art in the churches. He tried to pray but was very selfconscious.

As a young man, he relished his freedom, a false freedom which he later realised since there was no room for God. After completing secondary school in England, he won a scholarship to Clare College, Cambridge. But it was a disastrous year of drinking and sex and he fathered a child. His guardian sent him to the United States. In 1935, he enrolled in Columbia University in New York 
where he earned a BA and MA in English. Here, he made very good friends who remained friends all his life.

In February 1937, he bought The Spirit of Medieval Philosophy but was at first disgusted by the 'imprimatur ${ }^{1}$ he found in it. He had admired Catholic culture but had 'always been rather afraid of the Catholic Church' (Merton 1948:208). But through it he discovered an entirely new concept of God: God is Being Itself. Gradually, he began to attend various churches and in September 1938, he went to see Fr. George Barry Ford at Corpus Christi parish in New York and told him that he wanted to become a Catholic. He was baptised and received his First Communion on the 16th of November.

Like many new male converts, he almost immediately began to think of becoming a priest. He was attracted to the Franciscans but was told he could not enter because of his lifestyle at Cambridge.

Dan Walsh, one of his professors at Columbia, suggested that he make a retreat at the Trappist monastery of Our Lady of Gethsemani in Kentucky. During the retreat he wrote:

This is the center of America. I had wondered what was holding the country together, what has been keeping the universe from cracking in pieces and falling apart. It is places like this monastery - not only this one: there must be others ... This is the only real city in America - and it is by itself, in the wilderness. (Merton 1959:155)

He wrote that he had found what he was looking for (p. 168). But could he be a Trappist since the Franciscans had rejected him? After a short period of volunteer work at Friendship House in Harlem with the Baroness Catherine de Hueck Doherty, which raised another set of questions about his life's direction, he decided to go to Gethsemani and ask to be a monk there. He entered the monastery on 10 December 1941. After his novitiate, Father Louis as he was now known, made his simple vows in 1944, his solemn vows in 1947 and was ordained a priest in 1949. His autobiography Seven Storey Mountain was published in 1948 and immediately became a best-seller. He served as Master of Students and Master of Novices and became a full-time hermit on 20 August 1965. Exactly 27 years after he entered Gethsemani, he died in Bangkok on 10 December 1968.

\section{Merton's quest for his true self}

The purpose of the monastic life is set forth clearly in the Rule of Saint Benedict (Benedict of Nursia 1975) which is the basis of Trappist life. The first word of the 'Prologue' is 'Listen' with 'your heart' so that God will 'finish the good work begun' in a person, which describes the dynamic of continual growth in Christ. Monastic life is 'a school for God's service' (Prologue:45) in which 'heart expands and with the sweetness of love we move down the paths of God's commandments' (Prologue:45). The emphasis in the Rule is on obedience to God and to the abbot which will help the monk to monk on an active doing of the will of God. This dynamic of ongoing conversion to Christ, and to the Gospel, shaped Merton's life and gave direction to his quest for holiness.

However, there are three dimensions of Merton's life which interweave themselves as elements of tension throughout his monastic life. These form the matrix of his quest for holiness. These are his call to be a writer, his desire for solitude and his awakening realisation of the importance of the world's problems. Merton entered monastic life as a writer, he came to Gethsemani wanting a life of solitude and in 1941 he was determined to leave the 'world' he knew forever. Learning who he truly was in God, his true self, gradually shaped his understanding of holiness as not an escape from the world but as love for the world and its people from the perspective of monastic life.

\section{Merton the writer}

Merton began his monastic life with distinct writing gifts; he was a poet, had drafted several novels and regularly reviewed books for important publications. His literary agent Naomi Burton Stone was horrified by his decision to enter the Trappist since she said he was a natural writer and she feared that he might never write again. ${ }^{2}$ Besides a few books which he took with him to Gethsemani, Merton brought his writer self. But this was an unwelcome self.

His writings demonstrate that he was confident that his true vocation was as a monastic contemplative. He appears not to have struggled with the demanding, ascetic aspects of Trappist life - perhaps as both conscious and unconscious penance for his past life:

By this time I should have been delivered of any problems about my true identity. I had already made my simple profession. And my vows should have divested me of the last shreds of any special identity. But then there was this shadow, this double, this writer who had followed me into the cloister ... I cannot lose him. He still wears the name of Thomas Merton ... He is supposed to be dead ... I can't get rid of him ... And the worst of it is, he has my superiors on his side ... Nobody seems to understand that one of us has got to go ... There are days when there seems to be nothing left of my vocation - my contemplative vocation - but a few ashes. And everybody calmly tells me: 'Writing is your vocation'. (Merton 1948:490-491)

Gradually, he realised that his writer self was not a costume he could take on and off as he wished but that it was who he was - a monk, a contemplative artist with words. His journals have many entries with his complaints about wanting to be a contemplative, not a writer. But in 1949, he wrote:

At the same time I am finding myself forced to admit that my lamentations about my writing job have been foolish. Also I find that it helps me to pray because, when I pause at my work, I find that the mirror inside of me is surprisingly clean and deep and serene and God shines there and is immediately found, without hunting, as if He had come close to me while I was writing and I had not observed His coming. And this I think should be the cause of great joy, and to me it is. (Merton 1996a:338)

2.Personal conversation, Washington, DC, 1976. 
One dimension of Merton's understanding of holiness, his desire for union with God, was this realisation that his writer self was not to be cast away but was indeed who he was. He was not a monk-farmer (as were most of his brothers in community) but a monk-writer. The monastic life offered him time and solitude and resources in order to write; to run from these gifts was to try to be someone he was not.

\section{The call to solitude}

Trappist life is monastic life in community. But beginning early in his monastic life, Merton began to wonder if he was in the right place because of his profound desire for a life of solitude. Should he be a Carthusian or a Camaldolese monk in Europe? When he was preparing to make his final vows in 1949, he wrote:

\begin{abstract}
... it seemed to me that these vows will mean the renunciation of the pure contemplative life. If Jesus wants me to be here at Gethsemani, as my Superiors insist He does ... then perhaps $\mathrm{He}$ does not want me to be a pure contemplative after all ... Perhaps this is not the most perfect vocation in the Church, per se. Well, what about it? It seems to be my vocation ... But how can it be my vocation if I have such a strong desire for some other vocation? (Merton 1996a:39)
\end{abstract}

In the 1950s came invitations to be a hermit Cuernavaca in Mexico and Tortola in the British West Indies.

In December 1959, he received a letter from Rome which told him definitely that he could not leave Gethsemani and that 'they agreed with my superiors that I did not have an eremitical vocation. That therefore what they asked of me was to stay in the monastery where God had put me, and I would find interior solitude' (Merton 1996b:358).

For Merton, solitude - and eventually living as a hermit - was the environment of his true self. Writing just before he was told he must stay at Gethsemani, he said that 'The big reasons for solitude: the true perspective - leaving the 'world' - even the monastic world with its business, its vanities, superficiality... Solitude - witness to Christ - emptiness' (1996b:350).

His steps into the hermit life he desired came slowly. On 27 June 1949, Merton unexpectedly received permission to go out of the enclosure into the woods by himself. He wandered around this open area and later wrote: 'As soon as I get away from people the Presence of God invades me' (1996a:328).

On 29 December 1952, he decided to ask the abbot to be allowed to live as a hermit, there or elsewhere, at the end of three years. 'The new decision makes me feel the way I felt when I finally made up my mind to become a Catholic' (1996b:27).

In January 1953, he was given permission to spend time at a tool shed which he named 'St Anne's'. Gradually, over the next few years a hermitage evolved. In December 1960, he wrote about spending the afternoon in 'St Mary of Carmel' a cement block bungalow about a mile from the monastery.
During the next few years he was allowed to spend more time there, allowed to sleep over night occasionally (13 October 1964) until on 20 August 1965 he became a fulltime hermit, although because of the many visitors he had I would name him as a 'social hermit'.

He asserts that his hermit life is his true life. On 3 February 1966, he wrote, 'A basic conviction grows more and more clear to me. That I am called into solitude by God's will in order to be healed and purified' (Merton 1997:358). The word 'healed' is significant in Merton's understanding of holiness. The dynamics of monastic life confront the person with their light and their shadow. Recognising the shadow, the areas of one's life that can be frightening as they emerge from the unconscious in dreams and fantasies, is an essential part of the intricate process of healing.

Waldron quotes a section from Seeds of Contemplation which he asserts describes Merton's struggle with his shadow:

Therefore keep me, above all things, from sin. Keep me from the death of deadly sin which puts hell in my soul ... Set me free from the laziness that goes about disguised as activity when activity is useless, and from the cowardice that does what is not demanded in order to escape sacrifice. (quoted in Waldron 1994:74-75)

A key aspect of Merton's struggle with his shadow was to learn that holiness truly involved loving other people. It was the ongoing dynamic of the growth into the true self.

\section{Merton embraces the world}

Although John's Gospel states that 'God so loved the world that He gave His only Son' (Jn 3:16), love for the world was not Merton's conviction when he entered Gethsemani. Merton was happy to leave 'the world' in December 1941: New York, jazz, drink, sex, his friends. Gradually, he realised that what he despised in the world were his own feelings that he had projected on it. His true self was not whole until he embraced the world and its challenges, joys and problems.

His first trip outside the monastery since he entered in 1941 was on 14 August 1948. In his journal, he noted a small shift in his attitudes. He wrote:

Going into Louisville the other day I wasn't struck by anything particular. Although I felt completely alienated from everything in the world and all its activity, I did not necessarily feel out of sympathy with the people who were walking around. On the whole they seemed to me more real than they ever had before, and more worth sympathising with. (Merton 1996a:223)

In Seeds of Contemplation, he began to recognise that his identity cannot exclude others: 'I must look for my own identity, somehow, not only in God but in other men' (Merton 1949:35). This awareness continues to grow and in Sign of Jonas he comments that 'perhaps the things I resented about the world when I left it were defects of my own that I had projected upon it' (Merton 1953:87).

In 1951, he was able to see his monastic life in perspective and to realise that he now wanted to live in solidarity with others: 
Actually, I have come to the monastery to find my place in the world, and if I fail to find this place, I will be wasting my time in the monastery ... Coming to the monastery has been, for me, exactly the right kind of withdrawal. It has given me perspective. It has taught me how to live. And now I owe everyone in the world a share in that life. My first step is to start, for the first time, to live as a member of the human race which is no more (and no less) ridiculous than I am myself. (Merton 1953:314)

After Seven Storey Mountain was published, the 'world' reentered Merton's life through the massive correspondence which began and continued for the rest of his life. The many volumes of his letters testify to his vast correspondence with friends, literary icons such as Boris Pasternak, Pope John XXIII, people writing for spiritual guidance and activists such as Daniel Berrigan and Dorothy Day.

Merton's journey of individuation and holiness included the 'Louisville Fourth and Walnut' experience on 18 March 1958 in which he definitely experienced his common humanity with others. While standing at the corner, waiting for the light to change, the presence of God widened his inner vision in a most dramatic way:

In Louisville, at the corner of Fourth and Walnut, in the center of the shopping district, I was suddenly overwhelmed by the realisation that I loved all those people, that they were mine and I theirs, that we could not be alien to one another even though we were total strangers. It was like waking from a dream of separateness, of spurious self-isolation in a special world, the world of renunciation and supposed holiness. The whole illusion of a separate holy existence is a dream ... This sense of liberation from an illusory difference was such a relief and such a joy to me that I almost laughed out loud. And I suppose my happiness could have taken form in the words: 'Thank God, thank God that I am like other men, that I am only a man among others'. (Merton 1968b:156-157)

This was such a powerful experience that he wanted to tell people 'that they are all walking around shining like the sun' (p. 157). Soon after, he wrote that 'I must see and embrace God in the whole world' (Merton 1996b:200). God's love for the 'world' was now becoming essential to Merton's understanding of holiness. As 'a man among others' (p. 157) he could not despise the world and its people but as a monkwriter-hermit-social critic, he learned to embrace it and also speak words of prophetic critique.

\section{The true self and the false self}

Merton's 'true self' was his monk-writer-hermit-social critic self in search of profound union with God. First in Seeds of Contemplation (1949) and then in New Seeds of Contemplation (1961), he describes the 'true and false self'. ${ }^{3}$ In Wisdom of the Desert, his compilation of the sayings of the desert fathers, he stresses that

What the Fathers sought most of all was their own true self, in Christ. And in order to do this, they had to reject completely the

3.Waldron comments that Merton was preoccupied with the dynamic of the true and false self in Seeds of Contemplation because in the early stages of his career as monk/writer there was a tendency among his readers to canonize the young monk'. (Waldron 1994:73) false, formal self, fabricated under social compulsion in 'the world'. (Merton 1960:5-6)

Waldron states that Merton borrowed these concepts from Bernard of Clairvaux who discusses humility in relation to truth and self-knowledge (Waldron 1994:71). Bernard states: 'For we seek truth in ourselves, in our neighbours, and for its own sake (Bernard of Clairvaux 1987:106).

Merton describes the false self: 'Every one of us is shadowed by an illusory person: a false self ... My false and private self is the one who wants to exist outside the reach of God's will and God's love - outside of reality and outside of life. And such a self cannot help but be an illusion' (Merton 1961:34).

The journey from the false self to the true self is that of individuation, a Jungian term for the wholeness of the person, both psychologically and spiritually. ${ }^{4}$ The first step is that of ego-consciousness in which people live out of their persona - the face that they show to the world - and not their real self. An individuated person recognises the social necessity of a persona - a doctor has one role with her patients, another with her children - but that is not the sum total of the person's identity.

At some point in this journey the person confronts the shadow, which is real but unconscious. It makes its presence known through dreams, fantasies, active imagination, projections and 'Freudian slips'.

Merton's use of the word 'shadowed' relates directly to the individuation process since acknowledgement of the shadow contains the resources for deeper growth. Yet, he was trying to escape his shadow: 'The only true joy on earth is to escape from this prison of our self-hood...Short of this perfection, created things do not bring us joy but pain' (Merton 1949:16). But trying to evade one's shadow is self-defeating because it will not disappear but will continue to speak in different ways, especially for Merton in his projections. Merton needed to embrace his shadow so that it could be 'transformed into a positive source of energy the development of his personality' (Waldron 1994:75).

Gradually, Merton recognised that he was on the journey to his true self. In New Seeds of Contemplation, he expresses this in evocative language:

A tree gives glory to God by being a tree. For in being what God means it to be it is obeying Him. It 'consents,' so to speak, to His creative love ... But what about you? What about me? Unlike the animals and the trees, it is not enough for us to be individual men. For us, holiness is more than humanity. For me to be a saint means to be myself. Therefore the problem of sanctity and salvation is in fact the problem of finding out who I am and of discovering my true self. Trees and animals have no problem. God makes them what they are without consulting them, and

4.See also Donald Winnicott's interpretation of the true self and false self: (1965:140-151) in which he relates the development of these selves to the infant's
(1960) also Donald Winnicot's interpretation of the true self and false self: early interactions with her/his mother. 
they are perfectly satisfied. With us it is different. God leaves us free to be whatever we like. We can be ourselves or not, as we please. (Merton 1961:31-32)

The Epilogue of Sign of Jonas, 'Fire Watch, July 4, 1952' describes Merton's journey through the monastery at night to ensure that all was calm and no fire endangered the monastery. Waldron portrays this as 'a summary of the first phase of Merton's individuation (prior to and up to July 4, 1952) involving the integration of the various facets of his personality whose ultimate goal was psychic and spiritual wholeness' (1994:81). He moves through the various floors and rooms of the monastery, which Waldron describes as 'Merton's buffer against total engulfment by darkness (the unconscious) ... which 'aids him in delving into the deepest aspects of his psyche where he will confront many things about himself, about Gethsemani, and about the human family' (p. 85). Merton realises this when he describes the layers of Gethsemani - 'not only in length and height, but also in depth' (Merton 1953:347). The journey of individuation - to become one's true self - is a process of creativity:

Our vocation is not simply to be, but to work together with God in the creation of our own life, our own identity, our own destiny ... To put it better, we are even called to share with God the work of creating the truth of our identity ... The seeds that are planted in my liberty at every moment, by God's will, are the seeds of my own identity, my own reality, my own happiness, my own sanctity. (Merton 1961:32-33)

Since all persons are weak and incomplete, the journey is not to perfection but to integration and wholeness, a process of slowly and painfully bringing the scattered parts of oneself into unity in Christ. This is a faith journey in and through the Spirit of God, aided by prayer, spiritual direction and the collective wisdom of the Christian community.

The image of journey is most appropriate to describe the interface of wholeness and the true self. Merton, like all people, was a complex person, shaped by family, environment, culture and context (the 20th century) and his own distinct personality traits. His life-long journey to holiness and wholeness ended on 10 December 1968 in Bangkok. Much had been integrated as over the years he recognised both the True Self and the False Self within himself. There is never a clear moment in anyone's life in which they can say 'now I live from my True Self' (and certainly Merton never said this about himself) but rather one's true self in God emerges slowly over the years.

\section{Merton's true self as a-writer- social critic}

Merton's true self now included the social critic who was able to speak from his solitude. His stance towards the world was no longer condemnation and flight from it but of compassion. The '4th and Walnut' experience had so transformed his vision that he began to see all persons in the light of God. His solitude was not his own but it 'belongs to the world and to God' (Merton 1968b:19). He wrote that the world's political and economic problems are 'a crisis of man's spirit ... a great religious and moral upheaval of the human race' (Merton 1995c:83) and so beginning in the 1950s and continuing until his death, he wrote incisive essays on racism, nuclear weapons and peace and non-violence. The 'spiritual' Thomas Merton which people knew and liked now included the 'social' Merton who annoyed his monastic superiors and baffled some of his readers, while other persons such as Dorothy Day and Daniel Berrigan welcomed his prophetic voice.

Merton began to write on racism while the US civil rights movement led by Dr Martin Luther King Jr, whom he describes as 'perhaps one of the few really great Christians in America' (Merton 1996c:325) was gathering momentum. Writing about African Americans (then called Negroes), Merton maintained that they needed to claim their 'true selves' since the civil rights movement was not only about justice but was also a spiritual crisis in which 'the truth and authenticity of the person's spiritual identity are called into question' (p. 325).

In 'Letters to a White Liberal', Merton locates the source of the crisis within the white community and asserts 'Have we forgotten that the Negro is there because of us? His crisis is the result of our acts, and is, in fact our crisis' (Merton 1964:38). Writing to theologian Leslie Dewart in May-June 1963, Merton describes the current racial situation as 'being in the middle of a real American revolution, just as real as the one in 1776, and perhaps destined to have an even more decisive importance' (Merton 1994:292).

He criticises the Catholic Church for its timidity and lack of courage:

What has the Church done? She has made token and symbolic gestures of good will and justice. She has integrated schools and colleges in many areas. She has been less prejudiced than most other sectors of white society, and she has roundly condemned racial injustice on paper. She has shown good will and motherly concern. Apart from that, she has taken a safe position, neither too much of this nor too much of that, and has carefully avoided signs of haste in getting anywhere. (Merton 1994:292)

He stresses that the civil rights movement is an opportunity for conversion for white Christian America:

The American racial crisis which grows more serious every day offers the American Christian a change to face a realty about himself and recover his fidelity to orthodox truth, not merely in institutional loyalties and doctrinal orthodoxies (which no one has taken the trouble to accuse him of failing) but in recanting a more basic heresy: the loss of that Christian sense which sees every other man as Christ and treats him as Christ. (Merton 199d:226)

Writing about racism was controversial but speaking against nuclear weapons and the Cold War arms race led to his silence on these issues. In the early 1940s before he entered Gethsemani, Merton registered as a non-combatant since he viewed World War II as a just war of self-defence (Merton 1948:373-379). 
But nuclear weapons and the possibility of a nuclear war were an entirely different moral challenge:

We have to make ourselves heard. Christians have a grave responsibility to protest clearly and forcibly against trends that lead inevitably to crimes which the Church deplores and condemns. Ambiguity, hesitation and compromise are no longer permissible. War must be abolished. A world government must be established. We have still time to do something about it, but the time is rapidly running out. (Merton 1995b:47)

He was preparing a collection of his essays on peace and war, Peace in the Post-Christian Era, which included this statement:

I wish to insist above all on one fundamental truth: that all nuclear war, and indeed massive destruction of cities, populations, nations and cultures by any means whatever is a most serious crime which is forbidden to us not only by Christian ethics but by every sane and serious moral code. (Merton \& Burton 2004:19)

But its publication was forbidden, together with any writings on peace, by the abbot general of the order, Dom Gabriel Sortais. In a letter dated 12 May 1962, Merton was told to 'give up your intention of publishing the book you have finished, and abstain from now on from writing on the subject of atomic warfare, preparations for it, etc.' (Mott 1986:623). ${ }^{5}$

But Merton found another way to circulate his writings. Beginning in October 1961 and continuing for a year, Merton sent letters to various friends on the issues of peace and war. These letters were mimeographed, thus not subject to censorship and sent to a wide circle of friends. These 'Cold War Letters' were eventually published in $2006 .^{6}$

His prose poem Original Child Bomb, published in 1962, lays out starkly the progression of the idea of an atomic bomb to its deployment. Mott comments that it 'was perhaps the most telling thing Merton wrote against atomic warfare, worth far more than most articles on both sides of the debate in those early days of the controversy' (1986:370).

Merton saw the questions of nuclear weapons and war as fundamentally spiritual matters. He stated, 'The chief reason why we are drifting into nuclear war is that we are confused, empty and disoriented. We have no spiritual and ethical center' (Burton \& Merton 2004:19). Peace is living the truth. Merton asserted that the roots of war lie within the person as fear of the 'enemy', a nation or person who will kill them. He stated that our minds 'are just as filled with dangerous power today as the nuclear bombs themselves' (Merton 1995a:26).

In contrast to Dorothy Day, co-founder of the Catholic Worker movement, Merton was not a total pacifist. He wrote to her:

It is true that I am not theoretically a pacifist. That only means that I do not hold that a Christian may not fight, and that a war cannot be just. I hold that there is such a thing as a just war, even today there can be such a thing, and I think that the Church holds

5.This is the reference to the translation from the original French, fn 223 . The book was finally published in 2004 by Orbis Books.

6.See Thomas Merton (2006) it. But on the other hand I think that is pure theory and in practice all wars that are going around, whether with conventional weapons, or guerrilla wars, or the cold war itself, are shot through and through with evil, falsity, injustice and sin so much that one can only with difficulty extricate the truths that may be found here and there in the 'causes' for which the fighting is going on. (Merton 1985:145)

Merton developed principles for a spirituality of nonviolence, a way of living in peace in daily life. They are based on living the Beatitudes, especially Christ's teachings on being poor in spirit and being meek and merciful. Christian non-violence is thus a way of life - not a tactic for opposing a specific war or systemic injustice.

The trajectory of Merton's journey to his true self and his understanding of holiness took many years as gradually he faced towards the world which he thought he had definitively 'left' in 1941. As he discovered his profound bonds of common humanity with all persons, his contemplative vision led him to speak and write about the most pressing social and political issues of his time.

Merton gradually learned that holiness was not solitary and individual but communal and engaged with others and the challenges of one's time. This love for the world is not a distraction from prayer but one of the foundations of union with God for and with others. Merton spent a considerable number of his monastic years slowly learning this truth and when it truly transformed his consciousness as seen in the dramatic Louisville experience, he realised that for him, holiness was always world-affirming with a critical voice.

This communal understanding is undergirded theologically by Merton's stress that holiness is ecclesial. In Life and Holiness, he wrote that this 'is also a question of growth in Christ, deepening of our contact with him in and through the Church' which Merton was learning 'a closer union with our brethren in Christ ... in the living, growing spiritual organism of the Mystical Body' (Merton 1963:67).

The foundation of holiness is one's 'ontological union with God "in Christ"” (p. 70). All actions of the Christian faith prayer, personal charity, fidelity to one's commitment, action for justice - must be grounded in holiness which is 'our vital union with the Holy Spirit' (p. 71).

\section{Merton in love}

In March 1966, he had a back operation in a hospital in Louisville. The young student nurse whom he names as ' $\mathrm{M}$ ' (now known as Margie Smith) took care of him and they fell deeply in love. In the next few months, they exchanged many letters, talked on the phone and had a few visits which they treasured. They both had commitments: she was engaged (her fiancé was in the war in Vietnam) and he was a monk. They discussed marriage but he realised it would never work. 
This experience was his first adult love experience with a woman; as a young man, he had used women sexually though he had a few women friends such as Ginny Burton in New York. But this was the real thing. He now had to decide: marriage with $\mathrm{M}$ or solitude? He wrote: 'I love her completely, as I have never loved anyone in my life' (Merton 1997:81).

His abbot learned of their relationship and he was ordered to end it - which he did with much pain. Later he wrote of his embarrassment about this relationship and that he was 'completely drunk' when he loved her so passionately (Merton 1997:260). Yet, he also realised '... I recognise that it had a lot of good points because it brought out the things that had to come out and be recognised ... Keeping to the woods was what saved me' (p. 260).

His relationship with $\mathrm{M}$ marked the integration of his sexuality and was an important dimension of becoming his true self (Mott 1985:435-454). ${ }^{7}$ From seeing women as mostly sexual objects to be enjoyed - his youthful perspective - to leading a strict celibate life for many years - Merton discovered in this adult experience the transcending power of love. He died two years later and so we cannot know how Merton would have, over the years, understood his love for a cherished woman and love for God as essential to his quest for holiness.

\section{Conclusion$$
\text { 'Everything is emptiness and everything is }
$$$$
\text { compassion' }
$$

Over the years, Merton had developed interests in the great world religions: Buddhism (especially Zen), Hinduism, Islam and Taoism. In 1968, he travelled to Asia, visiting India, Sri Lanka, Singapore and Thailand, where he died.

In early December, of this year while he gazed at the gigantic statues of the Buddha at Polonnaruwa in Sri Lanka, Merton wrote:

Looking at these figures, I was suddenly, almost forcibly jerked clean out of the habitual, half-tidied vision of things, and an inner clearness, clarity, as if exploding from the rocks themselves, became evident and obvious ... All problems are resolved and everything is clear, simply because what matters is clear ... everything is emptiness and everything is compassion ... I mean, I know and I have seen what I was obscurely looking for. I don't know what else remains but I have now seen and have pierced through the surface and got beyond the shadow and the disguise. (Merton 1968a:233-236)

What Merton experienced and what he described was beyond words - yet, he wrote. But now he knew beyond words what he had desired. A week later he died.

Merton's life as a Trappist grew and developed from an initial desire to 'give up everything to God' to the realisation

7.Two recent books discuss Merton's relationship with M: Robert Waldron (2012), and Suzanne Zuercher (2014) that all things are found in God. His monastic life nourished his inner self and led him to a life of solitude as a hermit. His voice spoke clearly through his writings including his letters of the need for both prayer and social engagement - love of God and love of neighbour. Merton learned that holiness is the union of contemplation and compassion in which we find and live our true selves in God.

\section{Acknowledgements Competing interests}

The authors declare that they have no financial or personal relationships which may have inappropriately influenced them in writing this article.

\section{References}

Benedict of Nursia, 1975, The rule of St. Benedict, transl. A.C. Meisel \& M. L. del Mastro, Doubleday Image Books, Garden City, NY.

Bernard of Clairvaux, 1987, 'On the Steps of Humility and Pride', in Bernard of Clairvaux: Selected works, transl. G.R. Evans, pp. 99-143, Paulist Press, New York.

Gremmillion, J., (ed.), 1976, 'Justice in the World', The Gospel of peace and Justice, pp. 513-529, Orbis Books, Maryknoll, NY.

Merton, T., 1949, Seeds of contemplation, Dell Publishing Co., Inc., New York.

Merton, T., 1953, The sign of Jonas, Hollis \& Carter, London.

Merton, T., 1959, The secular Journal of Thomas Merton, Dell, New York.

Merton, T., 1960, The wisdom of the desert, New Directions, New York.

Merton, T., 1961, New seeds of contemplation, New Directions, New York.

Merton, T., 1963, Life and holiness, Geoffrey Chapman, London.

Merton, T., 1964, 'Letters to a White Liberal', in Seeds of Destruction, pp. 3-71, Farrar, Straus and Giroux, New York.

Merton, T., 1968a, The Asian Journal, New Directions, New York.

Merton, T., 1968b, Conjectures of a guilty bystander, Doubleday Image, Garden City, NY.

Merton, T., 1985, 'To Dorothy Day', in W.H. Shannon (ed.), The hidden ground of love: Letters on religious experience and social concerns, pp. 140-146, Harcourt Brace Jovanovich, Publishers, New York.

Merton, T., 1994, 'To Leslie Dewart', in W.H. Shannon (ed.), Witness to freedom: Letters in times of crisis, pp. 282-296, Harcourt Brace and Company, New York.

Merton, T., 1995a, 'The shelter ethic', in W.H. Shannon (ed.), Passion for peace: The social essays, pp. 20-26, Crossroad, New York.

Merton, T., 1995b, 'Nuclear war and Christian responsibility', in W.H. Shannon (ed.), Passion for peace: The social essays, pp. 37-47, Crossroad, New York.

Merton, T., 1995c, 'Christian action in world crisis', in W.H. Shannon (ed.), Passion for peace: The social essays, pp. 80-91, Crossroad, New York.

Merton, T., 1996a, 'The whale and the ivy', in J. Montaldo (ed.), Entering the silence: The journals of Thomas Merton, Volume Two 1941-1952, pp. 100-300, Harper San Francisco, San Francisco, CA.

Merton, T., 1996b, 'Master of Novices' in L.S. Cunningham (ed.), A search for solitude: The Journals of Thomas Merton, Volume Three 1952-1960, pp. 43-300, Harper San Francisco, San Francisco, CA.

Merton, T., 1996c,'The continuing need to question', in V.A. Kramer (ed.), Turning toward the world: The pivotal years. Journals, vol. 4: 1960-1963, pp. 250-350, Harper San Francisco, San Francisco, CA.

Merton, T., 1997, 'A midsummer diary for M., in C.M. Bochen (ed.), Learning to love. The journals of Thomas Merton, vol. 6: 1966-1967, pp. 301-349, Harper San Francisco, San Francisco, CA.

Merton, T. \& Burton P.A., 2004, Peace in the Post-Christian era, Orbis Books, Maryknoll, NY.

Merton, T., 2006, 'Letters' in C.M. Bochen \& W.H. Shannon, (eds.), Cold war letters, pp. 9-193, Orbis Books, Maryknoll, NY.

Mott, M.M., 1986, The seven mountains of Thomas Merton, Sheldon Press, London.

Waldron, R.G., 1994, Thomas Merton in search of His Soul: A Jungian Perspective, Ave Maria Press, Notre Dame, IN.

Waldron, R., 2012, Thomas Merton: The exquisite risk of love: The Chronicle of a Monastic Romance, Darton, Longman \& Todd, London.

Winnicott, D., 1965, "'Ego distortion in terms of the true and false self"', in The maturational processes and the facilitating environment, pp. 140-151, International Universities Presses, New York

Zuercher, S., 2014, The Ground of Love and Truth: Reflections on Thomas Merton's Relationship with the Woman Known as ' $M$ ', Extenso Press, Munhall, PA. 